\title{
The Use of Creative Problem Solving Based Genetic Mutation Module in Higher Education
}

\author{
Ghoffar Ismail Amar ${ }^{1}$, Suranto $^{2,3} \&$ Sajidan $^{2}$ \\ ${ }^{1}$ Postgraduate Student of Biology Education Department, Sebelas Maret University, Indonesia \\ ${ }^{2}$ Postgraduate of Biology Education Department, Sebelas Maret University, Indonesia \\ ${ }^{3}$ Department of Biology, Faculty of Mathematics and Natural Sciences, Sebelas Maret University, Indonesia \\ Correspondence: Suranto, Postgraduate of Biology Education Department, Sebelas Maret University, Indonesia.
}

Received: September 28, 2020

Accepted: December 14, 2020

Online Published: December 21, 2020

doi:10.5430/ijhe.v10n3p33

URL: https://doi.org/10.5430/ijhe.v10n3p33

\begin{abstract}
The creative problem solving (CPS) based on genetic mutation module provides students with an opportunity to identify problems, design a problem-solving plan, choose the right path, and effectively evaluate the solution. This research aims to examine the effectiveness of CPS-based genetic mutation module to improve problem-solving skills in undergraduate students of biological education. Furthermore, the CPS module was developed on the basis of research and development (R\&D) according to the Borg and Gall method and presented as a mutation module for genetic material. A group pre-test and post-test design was applied by undergraduate students of biological education at the university of Sebelas Maret in Surakarta using random sampling techniques. A total of 17 students from $5^{\text {th }}$ semester were accepted as participants and treated for pre-test and post-test. The instruments used for the collection of data was an essay test design based on Polya's indicators of problem-solving skills. In addition, this module was considered as an advantage in using large database storage technologies such as NCBI and ExPASy in order to solve the problem-solving process. The application of the module has been shown to be effective in improving students' problem solving skills from a very low to a moderately high level.
\end{abstract}

Keywords: creative problem solving, genetic mutation, module, undergraduate

\section{Introduction}

The development of biological learning in the $21^{\text {st }}$ century tends to grow rapidly, especially in technological development, and positive comments have been made on technological developments and discoveries in genetics as an influence on the development of the teaching of scientific activities in high schools and universities (Smith \& Wood, 2016). Genetic mutation is a complex material with technological and multidisciplinary developments. According to (Smith \& Knight, 2012), the topic of genetic mutation is a concept that requires a better ability to understand the complexity of the material it contains.

The genetic mutation material has been reported to be very useful in understanding the etiology and tendency of any hereditary disease that is hampered by ignorance of the basic concept of mutation (Antonarakis \& Cooper, 2013). An understanding of genetic mutations can also be used to process and verify the validity of information on current issues like the COVID-19 pandemic, as Phan (2020) recorded that, there were ninety-three mutations in all SARS-CoV-2 genome sampled. Meanwhile, Zhao \& Schuchardt (2019) stated that the perspective of process-based mutations is necessary in order to understand and analyze all phenomena of the effects of genetic mutations. Therefore, the topic of genetic mutation can be conveyed to the students not only through memorization but also in problem-solving skills training, in such a way that the concept of genetic mutation material becomes more real and understandable for the students.

These activities are related to various disciplines, therefore students need to work harder to achieve optimal skills (Prevost \& Lemons, 2016). This phenomenon was also recorded by Hong (2013) in which the complexity of the genetic mutation material requires students to have more ability to solve problems that need to be addressed according to technological developments. The importance of problem-solving skills for senior high school students requires pre-service biology teachers to practice problem-solving skills, including complex problem-solving skills, before applying to prospective students in the class (Bahtiyar \& Can, 2016). Furthermore, students should have better problem-solving skills to understand the causal relationship of any biological phenomenon and to master the 
appropriate scientific reasoning skills for each phenomenon encountered (Asiye \& Bilge, 2016). Pre-service biology teachers are like students who need training on how to use problem-solving skills before the application of any method, including the use of problem-solving skills to solve a problem.

There were several aspects, which includes (1) understanding the problem (identifying and understanding existing problems related to the data and conditions encountered), (2) devising a plan (looking for relationships between existing data and unresolved problems, gathering various information to solve a problem, and making problem-solving plans), (3) carrying out the plan (applying every draft prepared and information collected to solve the problem), and (4) looking back or examining and evaluating solutions to a problem applied (Carifio, 2015).

Woodin et al. (2010) examined all aspects of problem solving, it is very important that students have learn and apply learning outcomes in order to develop more complex problem solving skills to a higher level of intelligence. A person can be very intelligent when he can manage the information available to solve a problem (Căprioară, 2015). Based on Hajiyakhchali (2013) discovery, in which, learning that emphasizes on the CPS process can improve the student academic grades. This is in line with the statement by Fitri et al (2019) that the problem-solving framework can amplify the expertise in understanding concepts and high-order thinking skills (HOTS) in biological material. Mastery of the problem-solving skills on the concept of materials can be an indicator of good analytical thinking skills (Prawita et al., 2019) and will ultimately influence the academic grades of students (Hedjazi et al., 2012).

Based on the scientific results of PISA from 2018, Indonesia was ranked $10^{\text {th }}$ from the bottom (OECD, 2019) with an average scientific value of 396 points, which is below the average points of OECD countries 489. This result was in accordance with the profile pre-test of students taking genetic courses with an average problem-solving score of 46.4. With the following details, it is understandable that problem 61.8 , devising a plan 57.4, carrying out the plan 33.8 , and looking back 32.8 respectively.

Low problem-solving skills can be caused by learning environments and media that do not allow the maximum use of problem solving (Neo et al., 2012). According to Öner\& Sa (2009) problem solving can be facilitated by modules that allow group discussion to enable the exchange of information between students in the process of solving a multidisciplinary problems. Furthermore, the problem-solving skill process in solving multidisciplinary problems can also be maximized by applying CPS that connects student problem-solving and creative-thinking skills (Sophonhiranraka et al., 2015). The module integrated into each phase of the CPC can reduce the dominance of teachers in the learning process because when the teacher dominates the activity too much and offers too many concepts or procedures, student creativity in solving problem is suboptimal (Srikoon et al., 2018). The development of the CPS module can be used as a solution to multidisciplinary problems in genetic mutation material. This is supported by the statement of Plucker et al (2015) that creativity can facilitate alternative perspective in problem solving, when it is difficult to solve a problem and requires a new idea or a very suitable solution.

Bacanli et al (2011) also stated that creativity can generate more ideas to solve a problems and create something new. CPS is needed by students to face every new challenge and problem in each learning process such as biology (Phaksunchai et al., 2014), and it is believed to be a framework for solving all complex problems using creativity effectively (Treffinger et al., 2008). The learning integrated with the CPS model can help students solve complex problems innovatively and imaginatively (Parnes, 2015). Therefore, there is a need to conduct a research in order to find out if the CPS-based genetic mutation module can also be used to significantly improve student problem-solving skills. Preliminary findings indicated that the genetic mutation module based on creative problem solving was very effective in improving undergraduate student problem-solving skills.

\section{Method}

\subsection{Research Design}

This research aims to examine the effectiveness of the CPS-based genetic mutation module on undergraduate students' problem-solving skills. Furthermore, the CPS module was developed on genetic mutation material based on R\&D method used by Borg and Gall (Wahyuni et al., 2018). This type of research used in module testing is a pre-experimental one-group pretest-posttest design (Thyer, 2012). Yusop et al (2015) used a pre-test and post-test to determine the effectiveness of excellence camp for mathematics problem solving. The research design is shown in Table 1. 
Table 1. One group Pretest Posttest Study Research Design

\begin{tabular}{ccc}
\hline Pretest & Treatment & Posttest \\
\hline $\mathrm{O} 1$ & $\mathrm{X}$ & $\mathrm{O} 2$
\end{tabular}

In this experiment, an experimental class with modules was used in the field test. The research was conducted in 2 session of $4 \times 90$ minutes each, beginning with a problem-solving pre-test with genetic mutation material. The treatment with a CPS-based genetic mutation module was administered before changes in problem solving were measured followed by a posttest. The pretest results were used as the baseline for student problem-solving skills, while post-test results were used as the final scores to determine if the student problem-solving skills has increased, as a dependent variable after using the CPS module.

\subsection{Participant}

This research was conducted in the 2019/2020 academic year as part of the study program of biological education of Sebelas Maret University, especially for the employment of 17 students of $5^{\text {th }}$ semester offering courses on genetic consisting of 4 males and 13 females. Furthermore, it was carried out in the $5^{\text {th }}$ semester because genetic mutation material is part of the genetics course that must be offered by students. 17 students used as subjects already covered 30 percent of the total number of students in the $5^{\text {th }}$ semester (56) in the biological education program. This research was conducted without a control class because there was no comparison module available for students in the previous lesson.

\subsection{Instrument}

The instruments used for data collection includes pre-test and posttest essay tests. The assessment of the problem-solving tests was tailored to the aspects of Polya's problem solving developed by Carifio (2015) which consist of 4 indicators: (1) understanding the problem, (2) devising a plan, (3) carrying out the plan, and (4) looking back. The test consists of 8 essay questions with 2 questions on each aspect of problem solving. The questions used for the evaluation include the materials in the types of mutations, dominant-recessive mutations, mutation calculation, and mutation in cancer.

The quality of questions used was validated by experts with an average validation score of 92.93, which consists of the matter material score of 91.7, presentation of questions of 100, scoring of 87.5, knowledge dimension of 91.7, and knowledge process of 93.75 . Based on the scores, the questions are feasible and can be used to measure student problem-solving skills.

The data were collected before and after the treatments. After obtaining the scores through the pre-test and post-test, grouping was based on the high and low values of the score. The criteria for problem-solving skill levels were adapted from Lestari \& Djukri, (2019) as presented in Table 2.

Table 2. Criteria Problem-Solving Skill Levels

\begin{tabular}{cc}
\hline Score Range & Category \\
\hline $80<\mathrm{X} \leq 100$ & Very High \\
$60<\mathrm{X} \leq 80$ & High \\
$40<\mathrm{X} \leq 60$ & Moderate \\
$20<\mathrm{X} \leq 40$ & Low \\
$\mathrm{X} \leq 20$ & Very Low \\
\hline
\end{tabular}

(Lestari \& Djukri, 2019)

\subsection{Data Analysis Technique}

The data analysis technique used is a paired sample t-Test analysis with a significance level of 5\%. SPSS version 17 program was used for the entire tests. Kolmogorov-Smirnov test was used for the normality prerequisite test.

\section{Findings}

\subsection{Characteristics of Genetic Mutation Module Based on Creative Problem Solving}

CPS-based Genetic mutation module is a type developed based on the CPS syntax to guide students in order to identify problems, design a problem-solving plan, choose the right way, and evaluate it actively and independently. 
This module consists of learning outcomes, materials, methods, tools, or media, as well as learning and evaluation resources.

It was developed with the CPS syntax consisting of six stages (mess finding, fact finding, problem finding, idea finding, solution finding, and acceptance finding) to empower student problem-solving skills in the form of (1) identifying each phenomenon given to be filtered into problems for follow-up, (2) gathering information and data about the symptoms of the problems discovered, (3) identifying each problem and how to solve it, (4) looking for various ideas, options, methods, and tools to be selected as potential solutions or ideas, (5) exploring ideas in new and different ways and from different points of view to be developed into activity plans, and (6) finding ways to make ideas or solutions more effective and useful in genetic mutation material (Doak et al., 2013). Student activities in CPS learning are presented in Table 3.

Table 3. Student Activities in CPS Learning

\begin{tabular}{|c|c|c|}
\hline CPS Syntax & Module Activities & Students Activities \\
\hline Mess Finding & $\begin{array}{l}\text { Students were given several phenomena in the } \\
\text { form of genetic mutation cases or events that } \\
\text { occur in everyday life and were asked to } \\
\text { analyze the phenomena. }\end{array}$ & $\begin{array}{l}\text { Students can identify and analyze errors } \\
\text { from various phenomena that occur. }\end{array}$ \\
\hline Fact Finding & $\begin{array}{l}\text { Students were asked to write various } \\
\text { information obtained from the activities of } \\
\text { identifying phenomena. }\end{array}$ & $\begin{array}{l}\text { Students can identify and analyze } \\
\text { important data/information from various } \\
\text { phenomena that occur. }\end{array}$ \\
\hline Problem Finding & $\begin{array}{l}\text { Students are asked to associate facts with } \\
\text { problems to write the problem formulation } \\
\text { accordingly. }\end{array}$ & $\begin{array}{l}\text { Students can formulate problems in the } \\
\text { form of questions. }\end{array}$ \\
\hline Idea Finding & $\begin{array}{l}\text { Students were asked to explore various } \\
\text { sources and media to find useful information } \\
\text { for problem solving. }\end{array}$ & $\begin{array}{l}\text { Students can explore various media and } \\
\text { sources of literature to find various ideas, } \\
\text { options, and methods as solutions or new } \\
\text { ideas. }\end{array}$ \\
\hline Solution Finding & $\begin{array}{l}\text { Students were asked to give solutions from } \\
\text { various information obtained from previous } \\
\text { activities. }\end{array}$ & $\begin{array}{l}\text { Students can analyze literature and create } \\
\text { new points of view to solve the problems. }\end{array}$ \\
\hline $\begin{array}{l}\text { Acceptance } \\
\text { Finding }\end{array}$ & $\begin{array}{l}\text { Students were asked to elaborate on a series of } \\
\text { previous activities to make new knowledge } \\
\text { useful. }\end{array}$ & $\begin{array}{l}\text { Students can correlate various solutions } \\
\text { used to solve problems into new } \\
\text { knowledge that is useful for everyday life. }\end{array}$ \\
\hline
\end{tabular}

The following is a module developed based on CPS: 


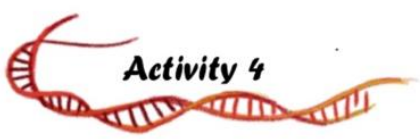

\section{Mess Finding \& Fact Finding}

Read and analyse the results of the following research journals carefully! After reading and analyse the following research journals, identify the facts and problems that arise!

The result from research journal "Mapping Point Mutations in the Drosophila rosy Locus Using Denaturing Gradient Gel Blots" found several genetic mutations that are presented in the table 4.1

Tabel 4.1 Types of ENU-induced single base change rosy mutations

\begin{tabular}{cccc} 
Base Change & Type & Total & Fraction of total (\%) \\
\hline $\mathbf{G} \rightarrow \mathbf{A}$ & Transition & 17 & 44,7 \\
$\mathbf{C} \rightarrow \mathbf{T}$ & Transition & 10 & 26,3 \\
$\mathbf{T} \rightarrow \mathbf{C}$ & Transition & 7 & 18,4 \\
$\mathbf{A} \rightarrow \mathbf{G}$ & Transition & 1 & 2,6 \\
$\mathbf{C} \rightarrow \mathbf{A}$ & Tranversion & 1 & 2,6 \\
$\mathbf{T} \rightarrow \mathbf{G}$ & Tranversion & 1 & 2,6 \\
$\mathbf{T} \rightarrow \mathbf{0}$ & Deletion & 1 & 2,6 \\
\hline
\end{tabular}

(Gray et al, 1991)

Problems and Facts Found:

Figure 1. Mess Finding and Fact Finding Stage in CPS-based module

\section{?. Problem Finding}

1. After identifying the problem based on the journals, make a few questions that arise as a formulation of a problem!

2. Write the hypothesis for the question asked!

Figure 2. Problem Finding Stage in CPS-based module 
E्थ] Idea Finding \& Solution Finding

\section{Brief Report of CP gene of JGMV-Krish}

A study of "coat protein sequence of Krish-infecting strain" in Johnsongrass mosaic potyvirus (JGMV) taken from the official Journal of Microbiology in Austria: "Archives of Virology", 143 (5), 1015-1020 by Suranto et al (1998) produced data about mutations that occur in the CP gene of the DNA base. Read and analyse the following comparation of bases and amino acids changes between JGMV-Jg (wildtype) and JGMV-Krish (Krish infecting strain) see Table bellow:

Tabel 4.2. Comparation base changes and amino acids JGMV-Jg \& JGMV-Krish

\begin{tabular}{|c|c|c|c|c|c|c|c|}
\hline \multirow{3}{*}{$\begin{array}{l}\text { Base } \\
8364 \\
8387\end{array}$} & \multirow{3}{*}{$\begin{array}{l}\text { Base change } \\
\mathrm{T} \rightarrow \mathrm{C} \\
\mathrm{G} \rightarrow \mathrm{A}\end{array}$} & \multicolumn{2}{|c|}{ Amino acid change } & \multirow{2}{*}{$\begin{array}{l}\text { Base } \\
8614\end{array}$} & \multirow{2}{*}{$\begin{array}{l}\text { Base change } \\
\mathrm{T} \rightarrow \mathrm{C}\end{array}$} & \multicolumn{2}{|c|}{ Amino acid change } \\
\hline & & $\mathrm{M} \rightarrow \mathrm{T}$ & & & & * & \\
\hline & & $\mathrm{E} \rightarrow \mathrm{K}$ & $5^{\prime}$ & 8635 & $\mathrm{~T} \rightarrow \mathrm{A}$ & * & \\
\hline 8398 & $\mathrm{~A} \rightarrow \mathrm{G}$ & * & & 8647 & $\mathrm{~A} \rightarrow \mathrm{G}$ & * & \\
\hline 8418 & $\mathrm{~A} \rightarrow \mathrm{G}$ & $\mathrm{K} \rightarrow \mathrm{R}(8)$ & & 8710 & $\mathrm{C} \rightarrow \mathrm{T}$ & * & \\
\hline 8437 & $\mathrm{C} \rightarrow \mathrm{A}$ & $*$ & $\mathrm{~N}$ & 8795 & $\mathrm{G} \rightarrow \mathrm{A}$ & $\mathrm{V} \rightarrow \mathrm{I}(134)$ & $\mathrm{CR}$ \\
\hline 8475 & $\mathrm{~T} \rightarrow \mathrm{C}$ & $\mathrm{V} \rightarrow \mathrm{A}(27)$ & & 8848 & $\mathrm{G} \rightarrow \mathrm{A}$ & $*$ & \\
\hline 8483 & $\mathrm{~A} \rightarrow \mathrm{G}$ & $\mathrm{T} \rightarrow \mathrm{A}(30)$ & & 8,910 & $\mathrm{~T} \rightarrow \mathrm{C}$ & $\mathrm{V} \rightarrow \mathrm{A}(172)$ & \\
\hline 8497 & $\mathrm{~T} \rightarrow \mathrm{G}$ & $\mathrm{D} \rightarrow \mathrm{E}(34)$ & & 8920 & $\mathrm{C} \rightarrow \mathrm{A}$ & $\mathrm{N} \rightarrow \mathrm{K}(175)$ & \\
\hline 8506 & $\mathrm{G} \rightarrow \mathrm{A}$ & $*$ & & 8921 & $\mathrm{~A} \rightarrow \mathrm{G}$ & $\mathrm{N} \rightarrow \mathrm{D}(176)$ & \\
\hline 8521 & $\mathrm{G} \rightarrow \mathrm{T}$ & * & CR & 9082 & $\mathrm{C} \rightarrow \mathrm{T}$ & $*$ & \\
\hline 8556 & $\mathrm{G} \rightarrow \mathrm{A}$ & $\mathrm{G} \rightarrow \mathrm{D}(54)$ & & 9142 & $\mathrm{G} \rightarrow \mathrm{A}$ & * & \\
\hline 8560 & $\mathrm{~A} \rightarrow \mathrm{T}$ & * & & 9196 & $\mathrm{C} \rightarrow \mathrm{T}$ & $*$ & \\
\hline 8588 & $\mathrm{~A} \rightarrow \mathrm{G}$ & $\mathrm{T} \rightarrow \mathrm{A}(65)$ & & 9298 & $\mathrm{C} \rightarrow \mathrm{T}$ & * & $\mathrm{C}$ \\
\hline
\end{tabular}

*) = indicate no change in amino acid at that site

Source: (Suranto et al, 1998.). GenBank: AAB94618.1

1. Based on the table above, what is the number of real mutations and silent mutations that occur in JGMV-Jg \& JGMV-Krish bases?

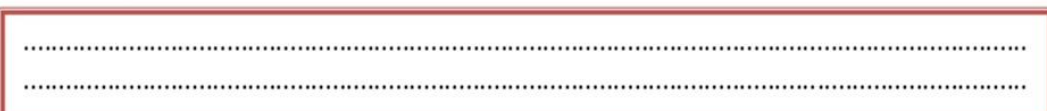

2. Does every mutation always change amino acids? How did it happen?

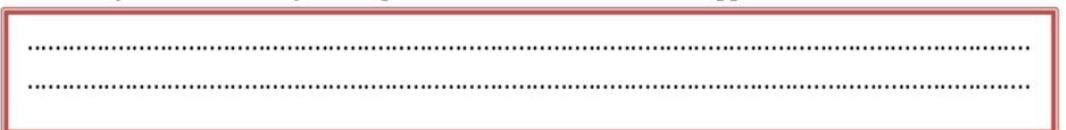

Figure 3. Idea Finding \& Solution Finding Stage in CPS-based module

\section{Exploring Genomic}

(Klug, et al, 2009)

Access NCBI at www.ncbi.nlm.nih.gov \& ExPasy site at http://www.expasy.ch/tools/sim-prot.html! Following are the amino acid sequences in two different people:

\begin{tabular}{|c|c|c|}
\hline & Person A & Person B \\
\hline 1 & MGNQMSVPQR VEDQENEPEA ETYKDNASAL & MGNQMSVPQR VEDQENEPEA ETYQDNASAL \\
\hline 31 & NGVPVVVSTH TVQHLEEVDL GISVKTDNVA & NGVPVVVSTH TVQHLEEVDL GISVKTDNVA \\
\hline 61 & TSSPETTEIS AVADANGKNL GKEAKPEAPA & TSSPETTEIS AVADANGKNL GKEAKPEAPA \\
\hline 9 & AKSRFFLMLS RPVPGRTGDQ AADSSLGSVK & AKSRFFLMLS RPVPGRTGDQ AADSSLGSVK \\
\hline & LDVSSNKAPA NKDPSESWTL PVAAGPGQDT & LDVSSNKAPA NKDPSESWTL PVAAGPGQDT \\
\hline
\end{tabular}


- Search reference sequence at GenBank: AAI26349.1 \& GenBank: EAW75574.1 for get the sequences database

1. Breast carcinoma amplified sequence 1 [Homo sapiens], GenBank: AAI26349.

2. Breast carcinoma amplified sequence 1, isoform CRA_a [Homo sapiens], GenBank: EAW75574.1

- Copy and paste each sequence in the "SEQUENCE" column. Use the sequence from Person A (AAI26349.1) for sequence 1 and the sequence form Person B (EAW75574.1) for sequence 2. Click "User-entered sequence" and give the name of the sequence. Click the "submit" button to compare the sequences.

Figure 4. Exploring Genomic in Idea Finding \& Solution Finding Stage

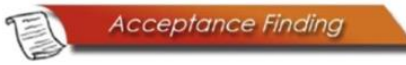

Based on the results of exploration \& problem solving, arrange it into a systematic scheme!

Figure 5. Acceptance Finding Stage in CPS-based module

3.2 The Results Of CPS-Based Genetic Mutation Module Application on The Problem-Solving Skills of Biology Education Undergraduate Students.

The results of the normality prerequisite test using the Kolmogorov-Smirnov test with SPSS 17 are obtained as follows.

Table 4. Test of Normality

\begin{tabular}{lrcc}
\hline & \multicolumn{3}{c}{ Kolmogorov-Smirnov $^{\mathrm{a}}$} \\
& Statistic & Df & Sig. \\
\hline PRETEST & .204 & 17 & .058 \\
POSTEST & .124 & 17 & $.200^{*}$ \\
\hline
\end{tabular}

a. Lilliefors Significance Correction

*. This is a lower bound of the true significance.

Table 4 showed that the significance value (p) in the Kolmogorov-Smirnov pre-test and post-test is more than the alpha value 0.05 ( $p>0.05$ ). Based on the Kolmogorov-Smirnov test, both pre-test (0.058) and post-test (0.2) were normally distributed. The difference in the significance of the use of the module is presented in Table 5.

Table 5. Results of Paired Samples t-Test

Paired Differences

\begin{tabular}{|c|c|c|c|c|c|c|c|c|c|}
\hline & \multirow[b]{2}{*}{ Mean } & \multicolumn{7}{|c|}{$\begin{array}{l}95 \% \text { Confidence } \\
\text { Interval of the } \\
\text { Difference }\end{array}$} \\
\hline & & & $\begin{array}{c}\text { Std. } \\
\text { Deviation }\end{array}$ & $\begin{array}{l}\text { Std. Error } \\
\text { Mean }\end{array}$ & Lower & Upper & $\mathrm{T}$ & $\mathrm{df}$ & $\begin{array}{c}\text { Sig. } \\
\text { (2-tailed) }\end{array}$ \\
\hline Pair 1 & $\begin{array}{c}\text { PRETEST - } \\
\text { POSTEST }\end{array}$ & -38.724 & 7.183 & 1.742 & -42.417 & -35.031 & -22.229 & 16 & .000 \\
\hline
\end{tabular}

Table 5 showed the significance of module with a value 0.000 , less than the alpha value of $0.05(<0.05)$, a null hypothesis was rejected, which means students problem solving skills were influence significantly before and after using the CPS module. These results indicated that CPS module was able to improved students problem solving skills effectively. The result of the correlations between pre-test and post-test are presented in Table 6, which showed that the average post-test score (65.69) was higher than the pre-test score (26.96). It indicated that students score increased after learning on genetic mutation material using the CPS module. 
Table 6. Paired Samples Correlations between Pre-Test and Post-Test

\begin{tabular}{rrrrrr}
\hline & & Mean & N & Std. Deviation & Std. Error Mean \\
\hline Pair 1 & PRETEST & 26.96 & 17 & 6.649 & 1.613 \\
& POSTEST & 65.69 & 17 & 9.174 & 2.225 \\
\hline
\end{tabular}

\section{Discussion}

This research focuses on improving student problem-solving skills using CPS in genetic mutation material. The results showed that the application of the CPS module can improve problem-solving skills. There is a significant influence of the module application on improving student problem-solving skills, which can be interpreted that each analyzing phenomena activities in the module can accommodate problem-solving skill. The CPS-based module scheme in accommodating students' problem-solving skills is shown in Figure 6.

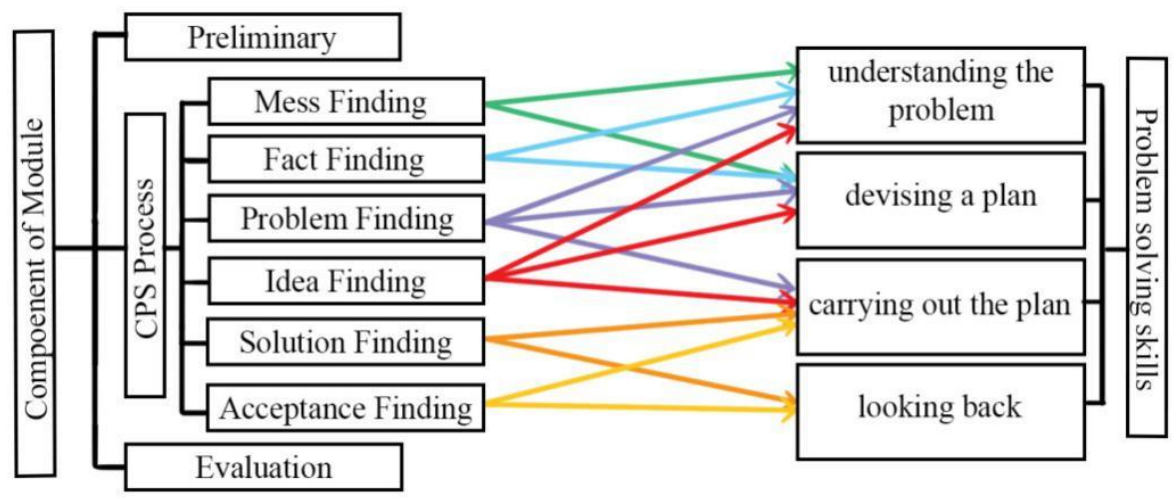

Figure 6. The CPS-based Module Scheme on Problem Solving Skills

The CPS phenomena presented by the lecturer at the mess and fact finding stages includes genetic diseases that occur in everyday life. Various phenotypes in individuals due to genetic mutations, calculation of genetic mutation, and genetic mutation detection technologies are widely discussed. The sources used in the presentation of the phenomena as problems resulted from scientific articles dealing with genetic mutations and research published in scientific journals.

The use of scientific literature and journals as phenomena was helpful in understanding the concept in which mutations occur, as well as the range of problems of genetic mutation interactions (Zhao \& Schuchardt, 2019). In addition, the process of analyzing scientific journals can be in a flexible way, therefore students can get used to understanding the biological phenomena (Coley \& Tanner, 2012). Understanding of the problem can therefore be maximized through the process of identifying and understanding existing problems in articles and research journals.

The process of identifying and analyzing problems in a particular phenomenon can also help reactivate prior knowledge by finding similarities between concepts mastered and newly discovered experience. Therefore, this procedure can help direct the students to solve problems (Meijer et al., 2006). In this process, students look for relationships between existing data and unresolved problems in designing a plan.

The results in Table 6 showed an increase in the mean scores of pre-test and posttest, an increase from 38.73 from 26.96 to 65.69. This increase is due to the use of the CPS process in the learning, which enable students to be more active in identifying problems, collecting data precisely and effectively, and mastering the concept, as well as having the concept of flexibility in finding solutions to a problem. (Asmidar, 2019). CPS also facilitates students to interact in groups in order to exchange information and ideas for solving problems between 4-5 members.

Group discussions conducted during the process of finding ideas \& solutions, includes identifying literature, analyzing, and evaluating ideas, are considered better than individual work (Mumford et al., 2001). The activity of group members to write down ideas and share with others enables interactive CPS group discussions to develop more potential problem-solving ideas (Brophy, 2006). Group work requires that they be open to ideas and suggestions from other students in order to offer other perspectives that might solve the problem. Furthermore, there is also an 
active exchange of information, clarification, and evaluation of ideas in the problem-solving process (McCormick et al., 2015).

The CPS module allows students to explore different sources to solve problems, and students can use various media such as the Internet or journals. Complex problem cannot be solved simply by storing facts from memory, but requires participation in the extraction of detailed information (Fischer et al., 2012). Students have problems directly with the research journals carried out as presented in Figure 1. Furthermore, they no longer memorize or explain the concepts of the process of transitions, transversions, and deletion. At this stage, they analyze the number of changes resulting from each process of transitions, transversions, and deletion, and also analyze the process of obtaining the fraction of total data presented. The high score on students' problem solving skills after studying with the CPS module is due to the fact that they can make better use of their reading and writing skills while reading and observing the problems in the module. These results was in line with the research conducted by Hoskinson et al., (2013) which states that scientific literacy used by students can result to broader ideas and solutions for solving complex problems.

Solving complex problems is also taught by studying genomics in the CPS module. The genomic research phase, integrated with technological developments in the field of genetics, gives students the experience of accessing databases on genetic mutations on public websites such as NCBI or ExPASy. The use of large integrated database from various sources can improve problem-solving skills and generate research-based findings (Campbell, 2003). The more resources are used, the more points of view are formed and lead to a deeper understanding and further refinement of problem-solving solutions (DeHaan, 2009).

The use of the CPS-based genetic mutation module in learning can improve students' understanding on the use of language and scientific terms. Their mastery of scientific language is well developed during the analysis of journal relating to research on genetic mutations. This can be seen during idea and solution finding stages as shown in Figure 3. Students were asked to analyze the journal about mutations in JGMV-Jg and JGMV-Krish. They face difficulty in analyzing the differences and the number of mutations that occur in JGMV-JG and JGMV-Krish bases as seen in the pre-test results showing a low average score of 19. The increase in the level of problem-solving skills is shown in Figure 7.

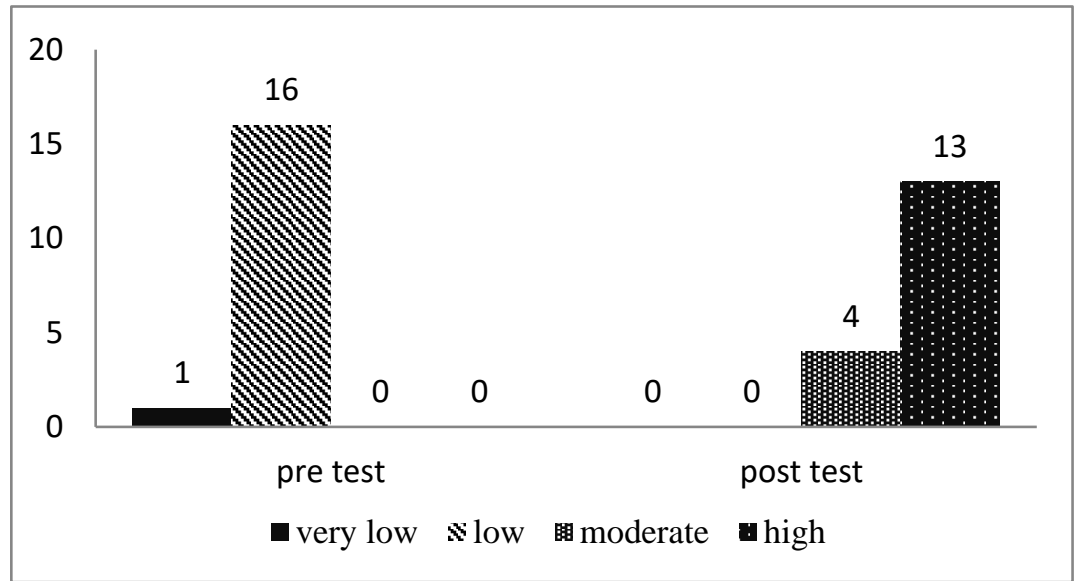

Figure 7. Total Students in Each Pretest-Posttest Problem Solving Skill Levels

As shown in Figure 7, student problem-solving skills increase before and after using the CPS module. The results of the pre-test showed that 1 student received the very low category with an average of 16.67 and 16 of the low category with an average score of 27.6. According to the post-test results, 4 students are from the moderate category with an average score of 54.17 and 13 are from the high category with an average score of 69.23. Using the CPS module can improve student problem-solving skills from very low to moderate-high levels. A student who was previously in the very low category with a score of 16.67 rise to a moderate level with a score of 45.83 , with an increase of 29.16. The effectiveness of using the CPS module in all aspect of problem-solving can be seen from the $\mathrm{N}$-gain score presented in Table 7. 
Table 7. The Result of N-gain score

\begin{tabular}{llll}
\hline No & Aspects of Problem Solving & N-gain Scores & Description \\
\hline 1 & Understanding The Problem & 0.35 & Medium \\
2 & Devising A Plan & 0.77 & High \\
3 & Carry Out The Plan & 0.60 & Medium \\
4 & Look Back & 0.39 & Medium \\
\multicolumn{2}{l}{ Average } & 0.53 & Medium
\end{tabular}

Table 7 showed that the average $\mathrm{N}$-gain score was categorize as medium (0.53), which means that the CPS module was effective in improving students' problem-solving skills. Understanding the problem aspects had the lowest $\mathrm{N}$-gain score (0.35), this is because students were not used to analyzing the phenomenon of genetic mutations in scientific journals with more complex problems. The process of identifying and analyzing a complex problem required persistence in order for students to adapt to solving of problems.

Meanwhile, devising a plan aspect had the highest N-gain score (0.77). Students were provided with many sources of information that can be accessed through the CPS-based modules during the learning process. This allows students to use different points of view in formulating and gathering information to solve a problem. In addition, the CPS-based module content optimizes group interaction in such a way that information exchange between group members takes place during the problem-solving planning process.

During the learning process with the CPS module, students were used to analyzing scientific journals in order to be familiar with scientific terms. They had difficulty identifying the difference between real and silent mutations previously because they only memorized definitions. Through the CPS-based module, students interact directly on the application of the theory of real mutations and silent mutations by dealing with the problem of differences in the number of mutations, as presented in Figure 3. They were then trained on flexibility to know the relationship between the number of mutations that mostly commonly occur with the concept of base bonds A-T and G-C. These concepts were then linked back to the problem of codon-triplet coding and the number of codon triplets that encode each amino acid.

The module also contains a log of the students' daily activities, such as cases of albino tiger breeding, breast cancer, and genetic mutations due to smoking. Students were also able to change the perspective that there are many problems when humans try to exploit albino tigers, increasing awareness of breast cancer and the associated risks of smoking. The complex and related problems in the CPS module provide adaptability for the students thinking flexibility in such a way that the concepts learned not only end up as rote learning but can also be applied directly to solve the problems. Each concept understood through the previous problem solving is further elaborated by new problems related to the previous concept.

Using large database storage technologies such as NCBI or ExPASy to solve problems can add another perspective regarding the given phenomenon. Applying the concepts learned using this technology also encourages students to see from different perspective in solving a problem, leading to an idea that the complex problem of genetic mutations can be solved with different perspectives in the field. The NCBI or ExPASy website was used for genomic research as shown in Figure 4. This enable the CPS module to focus on problem solving by maximizing students creativity to improve all aspect of problem-solving skills.

This improvement is inextricably linked to the process of developing the ideas and concepts learned in the last phase of the module. Students develop problem-solving ideas by creating a scheme that they can used in developing knowledge. The CPS module also provide an opportunity for students to evaluate and select ideas generated. The evaluation of ideas in CPS is used in the consideration of various criteria of the potential idea to solve complex problems (Giangreco et al., 2002). In addition, the students develop the ways/steps/procedures of potential methods that can be considered as solutions and the most appropriate ways/steps/procedures of methods as solutions (Isrokatun et al., 2018) in the form of useful information (Freeman et al., 2007).

Limiting the use of the CPS module is required more often than normal learning for best results. Students need more time to analyze journals and scientific articles to find solutions to the problem. The researcher suggests that students should first read the various phenomena presented in the module before classroom studying in such a way that they do not have to waste much time to understand the articles being presented and getting to master the genetic mutation material through the CPS module optimally. 
Using of public access websites like NCBI or ExPASy integrated into the module also requires more time coordination when students are not used to it. However, when they are familiar to and master the right concepts in the previous stages, this process won't take long. It is suggested that teachers should master the public access website used and condition their students well to avoid spending more time on the CPS-based module during the learning process.

\section{Conclusion}

Based on the discussion above, it can be concluded that the CPS-based genetic mutation module is effective at improving the problem-solving skills of students from very low to moderate-high levels. The results of paired Problem Solving Skills T-Tests showed that using the CPS module can help students solve complex problems as it is useful for generating ideas and solutions to problem solving. Each creative problem-solving phase built into the module helps students properly analyze each phenomenon in order to solve complex problems. Furthermore, using NCBI or ExPASy integrated into the module can add different perspective regarding the given phenomenon and improving the problem-solving skills. They can also learn genetic mutations independently through the module outside formal learning hours. For the implementation of the CPS module, it is suggested to ensure the use of the available Internet network, because it can support the exchange of information with group of friends, exploring ideas and solutions to solve problems, and accessing database on public access websites.

\section{Acknowledgements}

The authors express profound gratitude to Alanindra Saputra and the Undergraduate Students of Biology Education Sebelas Maret University for their support in the collection of data.

\section{References}

Antonarakis, S. E., \& Cooper, D. N. (2013). Human Gene Mutation in Inherited Disease: Molecular Mechanisms and Clinical Consequences. In Emery and Rimoin's Principles and Practice of Medical Genetics (Sixth Edit). Elsevier. https://doi.org/10.1016/B978-0-12-383834-6.00007-0

Asiye, B., \& Bilge, C. (2016). An investigation of problem-solving skills of pre-service science teachers. Educational Research and Reviews, 11(23), 2108-2115. https://doi.org/10.5897/ERR2016.3054

Asmidar, A. (2019). The Effect of Creative Problem Solving Model toward Students Learning Activities and Learning Outcomes of Science Learning, 178(ICoIE 2018), 92-94. https://doi.org/10.2991/icoie-18.2019.22

Bacanli, H., Dombayci, M. A., Demir, M., \& Tarhan, S. (2011). Quadruple thinking: Creative thinking. Procedia Social and Behavioral Sciences, 12, 536-544. https://doi.org/10.1016/j.sbspro.2011.02.065

Bahtiyar, A., \& Can, B. (2016). An investigation of problem-solving skills of pre- service science teachers. Academic Journals: Educational Research and Reviews, 11(23), 2108-2115. https://doi.org/10.5897/ERR2016.3054

Brophy, D. R. (2006). A Comparison of Individual and Group Efforts to Creatively Solve Contrasting Types of Problems. Creativity Research Journal, 18(January), 293-315. https://doi.org/10.1207/s15326934crj1803_6

Campbell, A. M. (2003). Public access for teaching genomics, proteomics, and bioinformatics. Cell Biology Education, 2(2), 98-111. https://doi.org/10.1187/cbe.03-02-0007

Căprioară, D. (2015). Problem Solving - Purpose And Means Of Learning Mathematics In School. Procedia - Social and Behavioral Sciences, 191, 1859-1864. https://doi.org/10.1016/j.sbspro.2015.04.332

Carifio, J. (2015). Updating, Modernizing, and Testing Polya's Theory of [ Mathematical ] Problem Solving in Terms of Current Cognitive, Affective, and Information Processing Theories of Learning, Emotions, and Complex Performances, 4(3), 105-117. https://doi.org/10.15640/jehd.v4n3a12

Coley, J. D., \& Tanner, K. D. (2012). Common origins of diverse misconceptions: Cognitive principles and the development of biology thinking. CBE Life Sciences Education, 11(3), 209-215. https://doi.org/10.1187/cbe.12-06-0074

DeHaan, R. L. (2009). Teaching Creativity and Inventive Problem Solving in Science. Cbe-Life Sciences Education, 8, 55-61. https://doi.org/10.1187/cbe.08-12-0081

Doak, C. K., Jambura, S. M., Knittel, J. A., \& Rule, A. C. (2013). Analyzing the Creative Problem-Solving Process: Inventing a Product from a Given Recyclable Item. Creative Education, 04(09), 592-604. https://doi.org/10.4236/ce.2013.49085

Fischer, A., Greiff, S., \& Funke, J. (2012). The Process of Solving Complex Problems. The Journal of Problem 
Solving, 4(1). https://doi.org/10.7771/1932-6246.1118

Fitri, R., Yogica, R., \& Lufri. (2019). Practicality of student worksheet based on concept and problem solving approach to improve student's ability to understand concept and high-level thinking in animal development. Journal of Physics: Conference Series, 1317(1). https://doi.org/10.1088/1742-6596/1317/1/012191

Freeman, S., O’Connor, E., Parks, J. W., Cunningham, M., Hurley, D., Haak, D., Dirks, C., \& Wenderoth, M. P. (2007). Prescribed Active Learning Increases Performance in Introductory Biology. CBE - Life Sciences Education, 6, 132-139. https://doi.org/10.1187/cbe.06-09-0194

Giangreco, M. F., Cloninger, C. J., Dennis, R. E., \& Edelman, S. W. (2002). Problem-Solving Methods to Facilitate Inclusive Education. Baltimore: Paul H. Brookes, 111-134.

Gray, M., Charpentier, A., Walsh, K., Wu, P., \& Bender, W. (1991). Mapping point mutations in the Drosophila rosy locus using denaturing gradient gel blots. Genetics, 127(1), 139-149.

Hajiyakhchali, A. (2013). The Effects of Creative Problem Solving Process Training on Academic Well-being of Shahid Chamran University Students. Procedia - Social and Behavioral Sciences, 84, 549-552. https://doi.org/10.1016/j.sbspro.2013.06.602

Hedjazi, S. Y., Shakiba, H., \& Monavvarifard, F. (2012). Effect of problem-solving Styles on academic achievement of agricultural students in the University of Tehran, 3(8), 4154-4158.

Hong, F. T. (2013). The role of pattern recognition in creative problem solving: A case study in search of new mathematics for biology. Progress in Biophysics and Molecular Biology, 113(1), 181-215. https://doi.org/10.1016/j.pbiomolbio.2013.03.017

Hoskinson, A. M., Caballero, M. D., \& Knight, J. K. (2013). How canwe improve problem solving in undergraduate biology? applying lessons from 30 years of physics education research. CBE Life Sciences Education, 12(2), 153-161. https://doi.org/10.1187/cbe.12-09-0149

Isrokatun, I., Hanifah, N., \& Maulana, M. (2018). Acceptance finding ability. IOP Conference Series: Materials Science and Engineering, 434(1). https://doi.org/10.1088/1757-899X/434/1/012295

Klug, W S., Michael, R S., Spencer, C A., Palladino, M A. (2009). Concepts of genetics. 9th ed. San Francisco : Pearson Benjamin Cummings, c2009.

Lestari, A. B., \& Djukri. (2019). The Problem-Solving Skills of Senior High School Students on Biology in Temanggung. IOP Conf. Series: Journal of Physics: Conf. Series 1241. https://doi.org/10.1088/1742-6596/1241/1/012019

McCormick, N. J., Clark, L. M., \& Raines, J. M. (2015). Engaging Students in Critical Thinking and Problem Solving: A Brief Review of the Literature. Journal of Studies in Education, 5(4), 100. https://doi.org/10.5296/jse.v5i4.8249

Meijer, J., Veenman, M. V. J., \& Van Hout-Wolters, B. H. A. M. (2006). Metacognitive activities in text-studying and problem-solving: Development of a taxonomy. Educational Research and Evaluation, 12(3), 209-237. https://doi.org/10.1080/13803610500479991

Mumford, M. D., Feldman, J. M., Hein, M. B., \& Nagao, D. J. (2001). Tradeoffs between ideas and structure: Individual versus group performance in creative problem solving. Journal of Creative Behavior, 35(1), 1-23. https://doi.org/10.1002/j.2162-6057.2001.tb01218.x

Neo, M., Neo, K. T. K., Tan, H. Y.-J., Joyce, Kwok, W.-J., \& Lai, C.-H. (2012). Problem-solving in a Multimedia Learning Environment: The MILE@HOME Project. Procedia - Social and Behavioral Sciences, 64, 26-33. https://doi.org/10.1016/j.sbspro.2012.11.004

OECD. (2019). PISA 2018 insights and interpretations. OECD Publishing, 64. https://www.oecd.org/pisa/PISA 2018 Insights and Interpretations FINAL PDF.pdf

Öner, F., \& Sa, U. (2009). The effects of students 'problem solving skills on their understanding of chemical rate and their achievement on this issue, 1, 2678-2684. https://doi.org/10.1016/j.sbspro.2009.01.473

Parnes, S. (2015). Creative Problem Solving Tools \& Techniques Resource Guide ". Creative Education Foundation. CreativeEducationFoundation.org 508.960.0000 \% 7C 413.658.0046 fax

Phaksunchai, M., Kaemkate, W., \& Wongwanich, S. (2014). Research and Development of a Training Package for Developing Creative Problem Solving of Undergraduate Students. Procedia - Social and Behavioral Sciences, 
116, 4824-4828. https://doi.org/10.1016/j.sbspro.2014.01.1032

Phan, T. (2020). Genetic diversity and evolution of SARS-CoV-2. Infection, Genetics and Evolution, 81(February), 104260. https://doi.org/10.1016/j.meegid.2020.104260

Plucker, J. A., Esping, A., Kaufman, J. C., \& Avitia, M. J. (2015). Creativity and intelligence. Handbook of Intelligence: Evolutionary Theory, Historical Perspective, and Current Concepts, 32(1981), 283-291. https://doi.org/10.1007/978-1-4939-1562-0_19

Prawita, W., Prayitno, B. A., \& Sugiyarto. (2019). Effectiveness of a generative learning-based biology module to improve the analytical thinking skills of the students with high and low reading motivation. International Journal of Instruction, 12(1), 1459-1476. https://doi.org/10.29333/iji.2019.12193a

Prevost, L. B., \& Lemons, P. P. (2016). Step by step: Biology undergraduates' problem-solving procedures during multiple-choice assessment. CBE Life Sciences Education, 15(4), 1-14. https://doi.org/10.1187/cbe.15-12-0255

Smith, M. K., \& Knight, J. K. (2012). Using the Genetics Concept Assessment to document persistent conceptual difficulties in undergraduate genetics courses. Genetics, 191(1), 21-32. https://doi.org/10.1534/genetics.111.137810

Smith, M. K., \& Wood, W. B. (2016). Teaching Genetics: Past, Present, and Future, 204(September), 5-10. https://doi.org/10.1534/genetics.116.187138

Sophonhiranraka, S., Suwannatthachoteb, P., \& Ngudgratokec, S. (2015). Factors affecting creative problem solving in the blended learning environment: a review of the literature, 174(1982), 2130-2136. https://doi.org/10.1016/j.sbspro.2015.02.012

Srikoon, S., Bunterm, T., \& Nethanomsak, T. (2018). Kasetsart Journal of Social Sciences Effect of 5P model on academic achievement, creative thinking, and research characteristics. Kasetsart Journal of Social Sciences, 39(3), 488-495. https://doi.org/10.1016/j.kjss.2018.06.011

Suranto, Gough, K. H., Shukla, D. D., \& Pallaghy, C. K. (1998). Coat protein sequence of Krish-infecting strain of Johnsongrass mosaic potyvirus. Archives of Virology, 143(5), 1015-1020. https://doi.org/10.1007/s007050050350

Thyer, B. A. (2012). Pre-Experimental Research Designs. In Etica e Politica (Vol. 15, Issue 1). Oxford University Press. https://doi.org/10.1093/acprof:oso/9780195387384.003.0002

Treffinger, D. J., Selby, E. C., \& Isaksen, S. G. (2008). Understanding individual problem-solving style : A key to learning and applying creative problem solving is. Learning and Individual Differences, 18(4), 390-401. https://doi.org/10.1016/j.lindif.2007.11.007

Wahyuni, T., Suwandi, S., Slamet, S. Y., \& Andayani. (2018). Contextual approach to the development of an Indonesian Syntax textbook in higher education in Indonesia. International Journal of Instruction, 11(1), 211-226. https://doi.org/10.12973/iji.2018.11115a

Woodin, T., Carter, V. C., \& Fletcher, L. (2010). From the National Science Foundation Vision and Change in Biology Undergraduate Education , A Call for Action - Initial Responses, 9, 71-73. https://doi.org/10.1187/cbe.10-03-0044

Yusop, H., Yeng, F. F., Jumadi, A., Mahadi, S., Ali, M. N., \& Johari, N. (2015). The Effectiveness of Excellence Camp: A Study on Paired Sample. Procedia Economics and Finance, 31(15), 453-461. https://doi.org/10.1016/s2212-5671(15)01174-0

Zhao, F. F., \& Schuchardt, A. (2019). Exploring students' descriptions of mutation from a cognitive perspective suggests how to modify instructional approaches. CBE Life Sciences Education, 18(3). https://doi.org/10.1187/cbe.18-11-0225

\section{Copyrights}

Copyright for this article is retained by the author(s), with first publication rights granted to the journal.

This is an open-access article distributed under the terms and conditions of the Creative Commons Attribution license (http://creativecommons.org/licenses/by/4.0/). 